\title{
THE TYPES AND CONDITIONS OF THE APPLICATION OF SPECIAL EVIDENTIARY PROCEDURES AND PREVENTIVE SECURITY MEASURES EMPLOYED BY SECURITY AGENCIES
}

\begin{abstract}
The modern society is facing an increasingly dangerous and serious manifestation of criminal activity, that utilizes the most modern technical achievements, especially in the field of communications. That is why the modern states resort to employing new procedural forms of gathering evidence at the cost of a certain infringement on the right to privacy and other human rights. The Criminal Procedure Code establishes six special evidentiary procedures. The most complex issue in special evidentiary procedures is the question of when their usage is justified, in other words, the type of criminal activity to which they can be applied, and the conditions under which they can be used. In addition to the special evidentiary actions established in the Criminal Procedure Code, the security agencies are, within their competences, authorized to secretly collect data by applying preventive and security measures provided by special laws (lex specialis). Having that in mind, this paper will deal with the questions concerning the types and conditions of the usage of special evidentiary procedures, as well as the types and conditions of the application of preventive and security measures in Republic of Serbia.
\end{abstract}

\footnotetext{
${ }^{*}$ LLD, Associate professor, The Faculty of Law for Commerce and Judiciary in Novi Sad, Serbia, e-mail: jelena@pravni-fakultet.info

** LLM, a PhD candidate at the Faculty of Law, The University of Belgrade, Serbia, e-mail: pocucamsara@gmail.com
} 
Keywords: Special Evidentiary Procedures, the Criminal Procedure Code, the Security Information Agency, the Military Security Agency, the Military Intelligence Agency

\section{Introduction}

During the last few decades, society has been facing ever more dangerous and severe manifestations of crime, the execution of which involves direct or indirect use of modern technological achievements, especially in the field of information-communication technologies. With regard to that we must not ignore the fact that contemporary forms of criminality are of a transnational character, and that the perpetrators are mostly organized groups. As a result, many countries resort to new procedural forms of gathering evidence, at the cost of relative infringement on the right to privacy and other human rights.

According to Škulić, "special evidentiary procedures are frequently identified as special evidentiary, or investigative techniques, and they represent certain evidence gathering methods which are atypical in character, and are therefore only applied in relation to certain criminal acts, which are, on one side, quite grave, i.e. serious, both in the factual sense relative to the consequences they produce in a general sense relating to life, and with respect to criminal law, regarding the punishment stipulated for them, while, on the other side, due to some of their phenomenological characteristics, and psychological and other traits of the perpetrators, such acts are very difficult to reveal, explain and prove through the application of the usual, or regular evidentiary methods". 1

According to Skakavac Z. and Skakavac T., "the use of special evidentiary procedures or special investigative techniques is of particular importance with respect to complex crime operations, such as money "laundering", corruptive and other financial crimes, and when these actions are committed in collusion with certain business entities, primarily banks and other financial organizations". ${ }^{2}$ Besides the cases identified above, other forms of organized crime such as "trade in narcotics, human trafficking, the smuggling of vehicles, cigarettes, weapons, etc., require the application of such measures". ${ }^{3}$

\footnotetext{
${ }^{1}$ Škulić, M. (2007). Krivično procesno pravo [Criminal Procedural Law]. Beograd, Pravni fakultet Univerziteta u Beogradu i JP Službeni glasnik, p. 307.

${ }^{2}$ Skakavac Z., Skakavac, T. (2017). Krivičnoprocesna regulacija posebnih dokaznih radnji u Republici Srbiji i njihova primena u savremenoj praksi [Criminal procedure regulation of special evidentiary actions in the Republic of Serbia and their application in modern practice]. Civitas, 7(2), p. 38.

${ }^{3}$ Ibid.
} 
The Criminal Procedure Code stipulates six separate kinds of evidentiary operations: secret communications surveillance, secret monitoring and recording, simulated operations, computer data searches, controlled delivery and undercover investigator. ${ }^{4}$

The most complex question relating to special evidentiary procedures is the question of their measure, i.e. the kinds of criminal acts to which they are applied and the conditions under which they are applied.

In addition to the special evidentiary procedures defined by the Code, the security services are, within their competences, authorized to secretly gather data by applying preventive-security measures stipulated by specific laws (lex specialis).

In view of the aforesaid, this paper will primarily be dealing with the general legal provisions on special evidentiary procedures (which criminal acts the special evidentiary procedures may be applied to (ratione materiae), the conditions of their application, and the primary characteristics of individual special evidentiary procedures), to be followed by discussion of the types and conditions of application of preventive-security measures by the security services in the Republic of Serbia.

\section{The legal provisions on special evidentiary procedures in the Republic of Serbia}

As Plazinić and Stojković point out, "in defining the general conditions for the application of special evidentiary procedures, the legislator took efforts to meet the requirements of subsidiarity and proportionality of their application". ${ }^{5}$ This is particularly important because "certain special evidentiary procedures have the essential common property of representing a certain legitimate way of surreptitious gathering of data which can have evidentiary significance, and the use of certain forms of "cunning", "deceit" and "fraud" allowed by the Code, which could in particular, with regard to undercover investigators, be identified with a kind of "espionage", or covert gathering of important data, but not relating to any foreign country or its authorities, its army, legal organizations etc., but primarily relating to members of organized crime groups". 6

\footnotetext{
${ }^{4}$ Zakonik o krivičnom postupku, [Criminal Procedure Code]. Službeni glasnik RS, no. 72/11, 101/11, 121/12, 32/13, 45/13, 55/14 and 35/19.

${ }^{5}$ Plazinić, M., Stojković, M. (2015). Primena posebnih dokaznih radnji i mehanizmi njihove kontrole [Application of special evidentiary actions and mechanisms of their control]. Tužilačka reč, 28, p. 17. ${ }^{6}$ Škulić, M. (2015). Tajni audio i video nadzor kao posebna dokazna radnja u Zakoniku o krivičnom postupku Srbije, [Secret audio and video surveillance as a special evidentiary action in the Criminal Procedure Code of Serbia]. Tužilačka reč, 28, p. 25.
} 
In this context, Matić Bošković points out that "the general rules according to which special evidentiary procedures are authorized relate to: 1 . the material requirement for undertaking special evidentiary procedures; 2 . handling the materials collected by means of special evidentiary procedures; 3. the question of evidentiary (in)validity of the information collected through special evidentiary procedures; 4 . incidental findings arrived at by special evidentiary procedures, and 5 . the secrecy of data related to special evidentiary procedures".?

Article 161 (paragraphs 1 and 2) of the Criminal Procedure Code stipulates that special evidentiary procedures may be authorized according to the person for whom there is reasonable suspicion that they committed a criminal act for which these special evidentiary procedures may be authorized, while there is no other way to gather the evidence for criminal prosecution, or its gathering would be quite difficult. Special evidentiary procedures may also be exceptionally authorized towards a person for whom there is reasonable suspicion that they are preparing any one of the criminal acts for which these evidentiary operations may be authorized, while the circumstances of the case indicate that the criminal act in question could not be revealed, prevented or proved to exist in any other way, or doing so would result in excessive difficulties or great danger.

As a result, the stipulated requirements for the authorization of special evidentiary operations are twofold and primarily relate to the degree of likelihood (grounds for suspicion) that a specific person has committed a criminal act for which these evidentiary operations may be ordered, and then to the restrictiveness with respect to their application. As the legal provision demonstrates, these operations may only be authorized if there is no other way to collect evidence for criminal prosecution, or if its collection would be quite difficult, which is estimated relative to the consequences of each particular case. The purpose of this conditionality in the application of special evidentiary procedures lies in the effort to reduce as much as possible any infringement of human rights, in particular the right to privacy.

Along those lines, Ilić points out that "the essential characteristics of special evidentiary procedures are: secrecy, limited (necessary) infringement of the guaranteed rights and liberties of man and citizen, and evidentiary

\footnotetext{
${ }^{7}$ Matić Bošković, M. (2015). Javni tužioci i primena posebnih mera tajnog prikupljanja podataka [Public prosecutors and the application of special measures of secret data collection] in: Petar Petrović (urednik) Posebne mere tajnog prikupljanja podataka u krivičnom postupku: pogled iz pravosuđa, [Special measures of secret data collection in criminal proceedings: a view from the judiciary]. Beograd, Beogradski centar za bezbednosnu politiku, p. 23.
} 
uselessness of results of those procedures if their application involved violation of any law, so that the essential characteristics of special evidentiary procedures also include restrictions for their use". 8

According to paragraph 3 of the same article, in deciding on the authorization and duration of special evidentiary procedures, the proceeding authority shall assess in particular if the same result could be achieved in a manner which would limit citizens' rights to a lesser extent.

According to Škulić, "special evidentiary procedures, and specific evidence collection techniques, are primarily characteristic for the preliminary investigation procedure. On the other hand, evidence results of special evidentiary procedures are certainly used, i.e. may be used in criminal procedure (if it is initiated), so that we also use the term "evidentiary techniques".

Article 162 of the Criminal Procedure Code stipulates that special evidentiary procedures may be authorized for the criminal acts: 1.) assigned by a special law to the public prosecution of specific competence; 2 .) the criminal acts itemized in the Code not assigned to the public prosecution of specific competence; and 3.) for prevention and obstruction of the presentation of evidence (article $336 \S 1$ of the Criminal $\operatorname{Code}^{10}$ ) if related to any of the criminal acts referred to above for which special evidentiary procedures may be authorized.

The Code also sets out the methods of handling the materials collected by undertaking special evidentiary procedures. Namely, according to article 163 (paragraph 1), if the public prosecutor does not institute criminal procedure within six months of the day of getting acquainted with the materials collected by means of special evidentiary procedures, or if they state they would not use them in the procedure, i.e. that they would not request any procedure to be conducted against the suspect, the judge for the previous procedure shall decide on destruction of the collected materials. In addition, paragraph 3 of

\footnotetext{
${ }^{8}$ Ilić, G. (2015). Posebne dokazne radnje u odlukama Vrhovnog kasacionog suda i Evropskog suda za ljudska prava [Special evidentiary actions in decisions of the Supreme Court of Cassation and the European Court of Human Rights] in: Petar Petrović (urednik) Posebne mere tajnog prikupljanja podataka u krivičnom postupku: pogled iz pravosuđa, [Special measures of secret data collection in criminal proceedings: a view from the judiciary]. Beograd, Beogradski centar za bezbednosnu politiku, p. 6.

${ }^{9}$ Škulić, M., (2016). Posebne dokazne radnje u funkciji suzbijanja terorizma i osnovni pravni aspekti protiv terorističkog delovanja vojnih snaga [Special evidentiary actions in the function of counter-terrorism and basic legal aspects of counter-terrorist activities of military forces]. Vojno delo 6, p. 276.

${ }^{10}$ Krivični zakonik, [Criminal Code]. no. 85/05, 88/05 - corr., 107/05 - corr., 72/09, 111/09, 121/12, 104/13, 108/14, 94/16 and 35/19.
} 
the same article specifies that, if the undertaking of special evidentiary procedures involved any breach of provisions of the Code or any orders of the proceeding authority, the collected data may not serve as basis for any court ruling, and the collected materials are dealt with according to provisions of article 84 of the Code which regulate the question of dealing with illegitimate evidence.

Besides the aforesaid, the Code also contains provisions on incidental findings and on data secrecy. Namely, article 164 stipulates that if special evidentiary procedures were undertaken to collect material on a criminal act or perpetrator not covered by the decision on the authorization of special evidentiary procedures, such materials may only be used in procedures if they relate to a criminal act that a special evidentiary procedure may be authorized for according to the law. Data secrecy under article 165 of the Code relates to the proposition for the authorization of special evidentiary procedures and the decision on the proposal, which are recorded in a specific register and kept together with the materials on the implementation of special evidentiary procedures in a special document file with the indication "special evidentiary procedures" and indication of the degree of secrecy, in accordance with regulations governing secret data. The data on the proposing, decision-making and the implementation of special evidentiary procedures constitute secret data. This data must also be kept secret by any other parties who may learn it in any capacity whatsoever.

To summarize the aforesaid, we can conclude that, as opposed to regular procedures, special evidentiary procedures may only be applied under the legally stipulated conditions and with respect to the legally stipulated criminal acts.

The following table presents the most important characteristics of individual special evidentiary procedures, with a view to understanding the conditions of application, basic characteristics and significance for criminal procedure. 


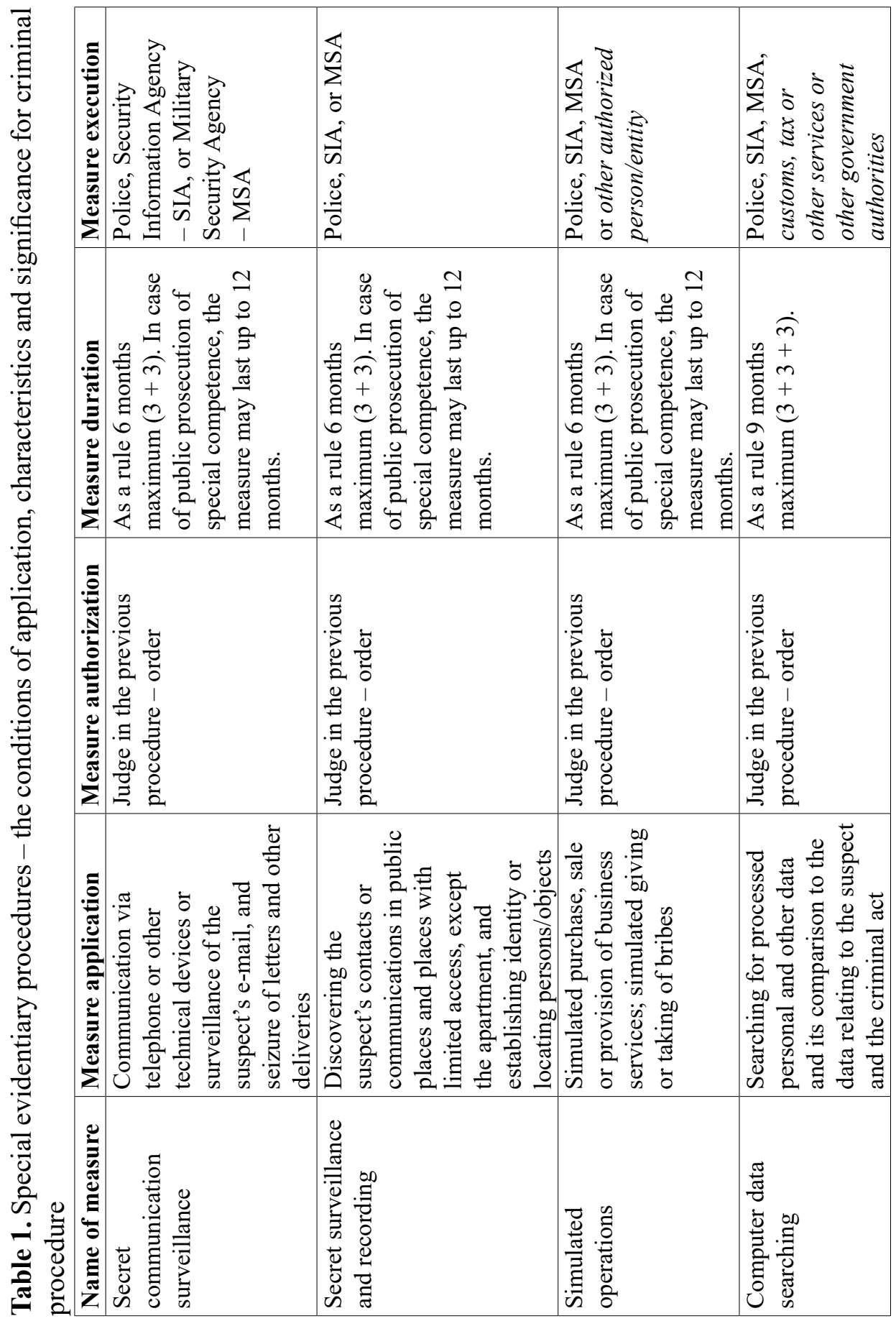




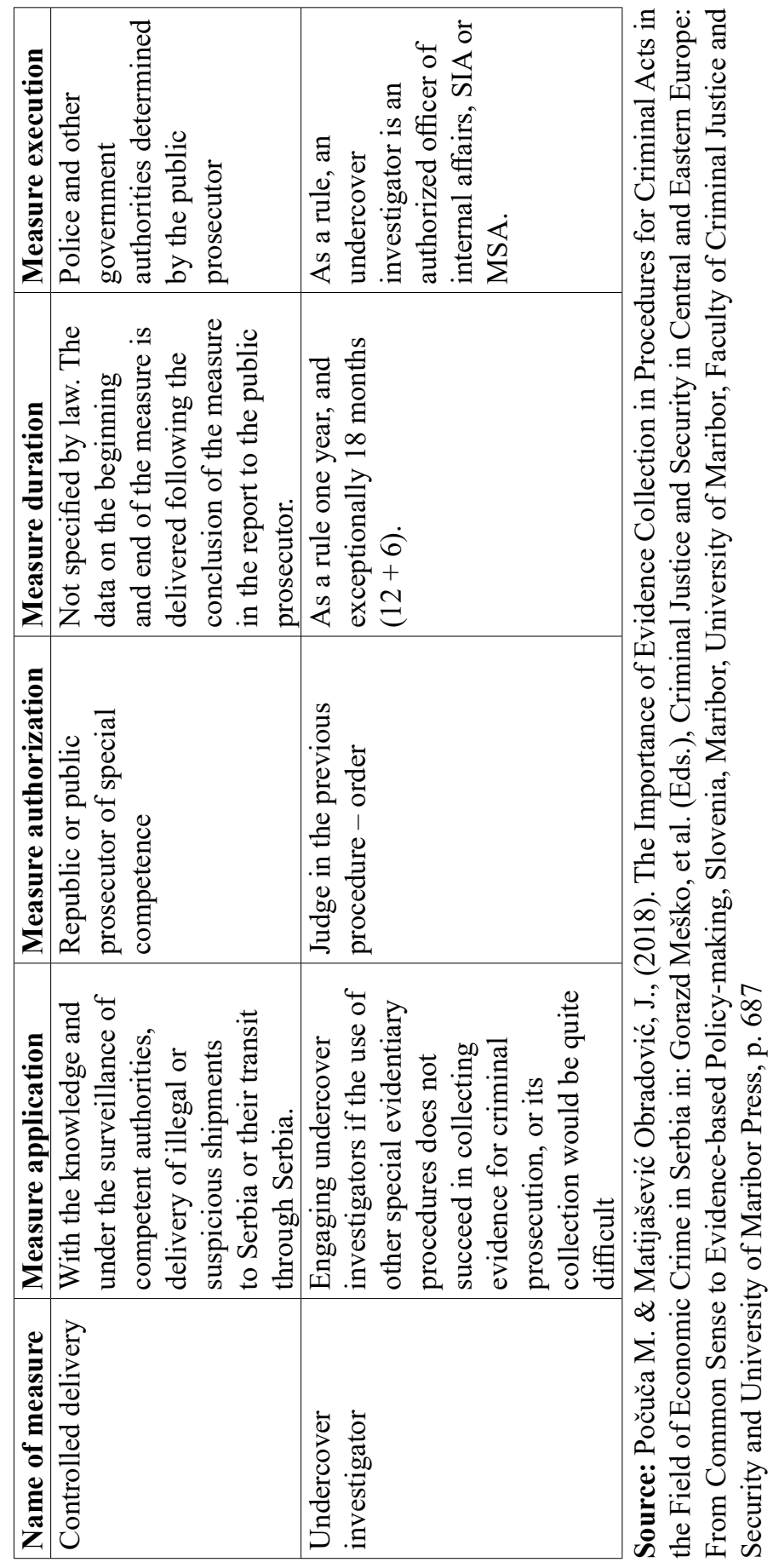




\section{Preventive-security measures of security services in the Republic of Serbia}

According to article 4 (paragraphs 1 and 2) of the Law on the Bases of Regulation of Republic of Serbia Security Services ${ }^{11}$, security services are the Security Information Agency as a special organization, Military Security Agency and Military Intelligence Agency, as administrative bodies within the Ministry of Defence. Security services perform duties and tasks within the scope of their competence, according to the law.

In the part dealing with parliamentary supervision over the work of security services (article 16, paragraph 2), this law stipulates that Republic of Serbia security services are authorized to apply specific procedures and measures of secret data collection.

As opposed to the Law on the Military Security Agency and the Military Intelligence Agency ${ }^{12}$, where special procedures and measures of secret data collection are specified in articles 12 and 27, the Law on the Security Information Agency ${ }^{13}$ defines specific measures which diverge from the inviolability of the secrecy of letters and other means of communication.

According to Milosavljević, "special procedures and measures may be defined as special powers of security authorities and criminal prosecution authorities to secretly collect data, which, in exceptional circumstances, for a certain period of time and without citizens' knowledge, based on a court ruling and under legally stipulated conditions, infringe on certain individual rights guaranteed by the Constitution". ${ }^{14}$ Essentially, "the data collected by means of such measures will serve to develop the extent of the grounds for suspicion against a certain individual, group of individuals or organization for a certain criminal act. In this way, based on clear and certain assumptions it will initiate and enable the filing of criminal charges". ${ }^{15}$

\footnotetext{
${ }^{11}$ Zakon o osnovama uređenja službi bezbednosti Republike Srbije, [Law on the Bases of Regulation of Republic of Serbia Security Services], Službeni glasnik RS, no. 116/07 and 72/12.

${ }^{12}$ Zakon o Vojnobezbednosnoj agenciji i Vojnoobaveštajnoj agenciji, [Law on the Military Security Agency and the Military Intelligence Agency]. Službeni glasnik RS, no. 88/09, 55/12 - decision US and $17 / 13$.

${ }^{13}$ Zakon o Bezbednosno-informativnoj agenciji, [Law on the Security Information Agency]. Službeni glasnik RS, no. 42/02, 111/09, 65/14 - dicision US, 66/14 and 36/18.

${ }^{14}$ Milosavljević, B. (2015). Pravni okvir i praksa primene posebnih postupaka i mera za tajno prikupljanje podataka u Republici Srbiji [Legal framework and practice of application of special procedures and measures for secret data collection in the Republic of Serbia] in: Petar Petrović (urednik) Posebne mere tajnog prikupljanja podataka: između zakona i sudske prakse, [Special measures for secret data collection: between law and case law]. Beograd, Beogradski centar za bezbednosnu politiku, p. 11.

${ }^{15}$ Lazić, R. (2015). Sudska kontrola zakonitosti u radu službi bezbednosti Srbiji, [Judicial control of legality in the work of security services in Serbia]. Zbornik radova Pravnog fakulteta u Novom Sadu 1, p. 160.
} 
Based on the above definition, Milosavljević derives two essential characteristics of special procedures and measures.

Namely, "the first essential characteristic of special procedures and measures could be the fact that their application specifically restricts individual rights and liberties. This specific nature is reflected in their secrecy, a quality which is hardly reconcilable to the concept of democracy and the fundamental ideas of human rights". ${ }^{16}$

The second essential characteristic of special procedures and measures is tied to the aforesaid, so that Milosavljević points out that special procedures and measures are "only allowed in cases of serious criminal acts and more severe forms of national security risks, on the condition that there exist at least grounds for suspicion which point to such acts taking place. They are only applied when other measures (which with less risk, i.e. in a non-secret way, infringe on certain rights) cannot achieve a legitimate goal". ${ }^{17}$

Bearing in mind that in case of application of special procedures and measures in a particular situation the right of an individual becomes secondary to the interests of the whole society, Mirković points out that they "represent a compromise between the need to protect the public interest in a specific situation and the general rule that in every situation the government authorities have the obligation to respect human rights and liberties". ${ }^{18}$

In view of the aforesaid, we cannot disregard the standpoint of some authors which relates in particular to criminality forms with regard to which the use of special procedures and measures is allowed. Namely, "it is exactly criminality characteristics that represent the necessary indicators for the planning and organization of work of competent government authorities, primarily internal affairs authorities. The resolution of any problem, including the problem of criminality, requires the selection of the adequate instruments and organization models for efficiency to be achieved". ${ }^{19}$

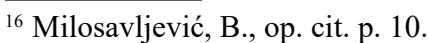

${ }^{17}$ Ibid., p. 11.

${ }^{18}$ Mirković, V. (2017). Sudska kontrola specijalnih istražnih mera službi bezbednosti u Republici Srbiji, [Judicial control of special investigative measures of the security services in the Republic of Serbia]. NBP - Žurnal za kriminalistiku i pravo 22(3), p. 90.

${ }^{19}$ Đurđević, Z., (2007). Pojam i vrste analize kriminaliteta, [The concept and types of crime analysis]. NBP-žurnal za kriminalistiku i pravo 12(1), pp. 93-109; Živanović, K., (2018). Posebna dokazna radnja tajnog nadzora komunikacije - Praksa Evropskog suda za ljudska prava u slučaju neobrazložene naredbe suda, [Special evidentiary action of secret surveillance of communication - The practice of the European Court of Human Rights in the case of an unexplained court order]. NBP - Žurnal za kriminalistiku i pravo 23(3), p. 288.
} 
According to article 13 of the Law on the Security Information Agency, special measures which diverge from the inviolability of the secrecy of letters and other communication means are: 1) secret surveillance and recording of communication, irrespective of the form and technical devices by which it is performed, or email or other address surveillance; 2) secret surveillance and recording of communication in public places and places with restricted access, or in rooms; 3 ) statistical electronic surveillance of communication and information systems with a view to collecting data on the communication or the location of the mobile terminal equipment used; 4) computer searching of processed personal or other data and its comparison to the data collected by applying previous measures.

Alongside the special measures from the first two points, secret surveillance and recording may be approved for places, premises and objects, also including automatic data processing devices and equipment where electronic records are, or may be kept.

According to article 14 of the same legal text, special measures may be authorized in relation to a person, group or organization for which there is reasonable suspicion that they undertake or prepare actions directed against the security of the Republic of Serbia, while the circumstances of the case indicate that those actions could in no other way be discovered, prevented or proved to take place, or that would cause inordinate difficulties or great danger. In deciding on the authorization and duration of special measures, it would be considered in particular if the same result could be achieved in a way which involves lesser restrictions of citizens' rights, in the scope necessary to satisfy the purpose of the restrictions in a democratic society.

In addition to the aforesaid, article 15 defines that the court may order the application of a special measure, on the justified proposal of the Agency director, if the aforesaid conditions are met.

Article 12, paragraph 1 of the Law on the Military Security Agency and the Military Intelligence Agency, specifies special procedures and measures of secret data collection within the competence of the Military Security Agency to be the following: 1) operative infiltration of organizations, groups and institutions; 2) surreptitious collection and purchase of documents and objects; 3) secret inspection of data entries, in line with the law; 4) secret following and surveillance of persons in open spaces and public places with the use of technical devices; 5) secret electronic surveillance of telecommunications and information systems for collecting stored data on telecommunications activities, without access to their content; 6) secret recording and documenting of conversations in open and closed spaces with the use of technical devices; 7) 
secret surveillance of the contents of letters and other means of communication, also including secret electronic surveillance of the content of telecommunications and information systems; 8) secret surveillance and recording of the interior of facilities, closed spaces and objects.

Paragraph 2 of the same article stipulates that the application of special procedures and measures is ordered by the minister of defence, at the proposal of the director of the Military Security Agency, based on the opinion of the National Security Council.

Article 27, paragraph 1 of the same legal text specifies special procedures and measures of secret data collection within the competence of the Military Intelligence Agency to be the following: 1) secret cooperation with natural persons and legal entities for the purpose of gathering data and information of military, military-political, military-economic nature, and other data and information which relate to a proliferation of weapons and military equipment, and threats of terrorism directed from abroad towards the Republic of Serbia defence system; 2) secret collection and purchase of documents and objects; 3) operative infiltration of organizations, institutions and groups; 4) taking measures aimed at concealment of identity and property; 5) the establishment of legal entities and the organization of their operations in such a way that they are not related to the Military Intelligence Agency; 6) surreptitious use of the property and services of natural persons and legal entities subject to compensation; 7) the use of special documents and devices which protect the Military Intelligence Agency, its members, premises and assets.

The same article (paragraphs 2 and 4) defines that special procedures and measures are taken based on the order of the director of the Military Intelligence Agency or a person authorized by them, while the application of special procedures and measures is regulated by the defence minister, at the proposal of the director of the Military Intelligence Agency, subject to the opinion of the National Security Council.

\section{Conclusion}

Given their nature and character, and the effects they produce in practice, special evidentiary procedures are the subject of many discussions, even polemics, especially with regard to their extent, or the way in which they are applied and the types of criminal acts they apply to.

Namely, in theory and practice alike, different observations are offered relating to whether it is more advisable to develop a repressive response keeping up with the development of criminal activities, to the detriment of liberties 
and rights of individuals, or it is rather important to move in the opposite direction, and allow the repressive response of the state to lag behind the (very expansive) dynamics of the development of modern crime forms. What is certainly the case is that alongside taking a selective approach in terms of the number of the measures and the contents of each individual measure, we must make sure an adequate balance is maintained in the application of special evidentiary procedures, as a too broad application certainly leads to encroachment on human rights and liberties, while a too narrow application results in their effect being totally lost.

In addition, after a brief overview of the preventive-security measures of the security services, we may conclude that at this point, according to the three applicable legal texts (the Criminal Procedure Code, the Law on the Security Information Agency and the Law on the Military Security Agency and the Military Intelligence Agency) there exist in total 25 special measures and procedures, and this situation leads us to the question of the justifiability of existence of so many special measures and procedures, and the need for their future harmonization with respect to their corresponding terms and content.

\section{Matijašević Jelena}

Prof. dr, Pravni fakultet za privredu i pravosuđe Univerziteta Privredna akademija u Novom Sadu, Srbija

\section{Zarubica Sara}

Msr, doktorand na Pravnom fakultetu Univerziteta u Beogradu, Srbija

\section{VRSTE I USLOVI PRIMENE POSEBNIH DOKAZNIH RADNJI I PREVENTIVNO-BEZBEDNOSNIH MERA SLUŽBI BEZBEDNOSTI}

REZIME: Savremena društva suočavaju se sa sve opasnijim i težim oblicima kriminala u čijem izvršenju se koriste najsavremenija tehnička dostignuća, naročito u oblasti komunikacija. Zato savremene države pribegavaju novim procesnim formama prikupljanja dokaza po cenu izvesnog 
zadiranja u pravo privatnosti i druga ljudska prava. Zakonik o krivičnom postupku utvrđuje šest posebnih dokaznih radnji. Najsloženije pitanje kod posebnih dokaznih radnji je pitanje njihove mere, odnosno vrste krivičnih dela na koja se primenjuju i uslova pod kojima se primenjuju. Pored posebnih dokaznih radnji predviđenih u Zakoniku o krivičnom postupku, službe bezbednosti su u okviru svojih nadležnosti ovlašćene da tajno prikupljaju podatke primenom preventivno-bezbednosnih mera predviđenih posebnim zakonima (lex specialis). Imajući u vidu rečeno, rad će se baviti pitanjima o vrstama i uslovima primene posebnih dokaznih radnji, kao i o vrstama i uslovima primene preventivno-bezbednosnih mera u Republici Srbiji.

Ključne reči: posebne dokazne radnje, Zakonik o krivičnom postup$k u$, Bezbednosno-informativna agencija, Vojnobezbednosna agencija, Vojnoobaveštajna agencija.

\section{References}

1. Đurđević, Z. (2007). Pojam i vrste analize kriminaliteta, [The concept and types of crime analysis]. NBP - žurnal za kriminalistiku i pravo 12(1), pp. 93-109

2. Ilić, G. (2015). Posebne dokazne radnje u odlukama Vrhovnog kasacionog suda i Evropskog suda za ljudska prava [Special evidentiary actions in decisions of the Supreme Court of Cassation and the European Court of Human Rights]. in: Petar Petrović (urednik) Posebne mere tajnog prikupljanja podataka u krivičnom postupku: pogled iz pravosuđa, [Special measures of secret data collection in criminal proceedings: a view from the judiciary]. Beograd, Beogradski centar za bezbednosnu politiku, pp. 4-21

3. Krivični zakonik [Criminal Code]. Službeni glasnik RS, no. 85/05, 88/05 corr., 107/05 - corr., 72/09, 111/09, 121/12, 104/13, 108/14, 94/16 and 35/19

4. Lazić, R. (2015). Sudska kontrola zakonitosti u radu službi bezbednosti Srbiji [Judicial control of legality in the work of security services in Serbia]. Zbornik radova Pravnog fakulteta u Novom Sadu 1, pp. 157-178

5. Matić Bošković, M. (2015). Javni tužioci i primena posebnih mera tajnog prikupljanja podataka [Public prosecutors and the application of special measures of secret data collection] in: Petar Petrović (urednik) Posebne mere tajnog prikupljanja podataka u krivičnom postupku: pogled iz pravosuđa, [Special measures of secret data collection in criminal proceedings: a view from the judiciary]. Beograd, Beogradski centar za bezbednosnu politiku, pp. 21-30 
6. Milosavljević, B. (2015). Pravni okvir i praksa primene posebnih postupaka i mera za tajno prikupljanje podataka u Republici Srbiji, [Legal framework and practice of application of special procedures and measures for secret data collection in the Republic of Serbia]. in: Petar Petrović (urednik) Posebne mere tajnog prikupljanja podataka: između zakona i sudske prakse, [Special measures for secret data collection: between law and case law]. Beograd, Beogradski centar za bezbednosnu politiku, pp. 5-33

7. Mirković, V. (2017). Sudska kontrola specijalnih istražnih mera službi bezbednosti u Republici Srbiji, [Judicial control of special investigative measures of the security services in the Republic of Serbia]. NBP Žurnal za kriminalistiku i pravo 22(3), pp. 89-105

8. Plazinić, M., Stojković, M. (2015). Primena posebnih dokaznih radnji i mehanizmi njihove kontrole, [Application of special evidentiary actions and mechanisms of their control]. Tužilačka reč, 28, pp. 14-23

9. Počuča M., Matijašević Obradović, J. (2018). The Importance of Evidence Collection in Procedures for Criminal Acts in the Field of Economic Crime in Serbia in: Gorazd Meško, et al. (Eds.), Criminal Justice and Security in Central and Eastern Europe: From Common Sense to Evidence-based Policy-making, Slovenia, Maribor, University of Maribor, Faculty of Criminal Justice and Security and University of Maribor Press, pp. 671-681

10. Skakavac Z., Skakavac, T. (2017). Krivičnoprocesna regulacija posebnih dokaznih radnji u Republici Srbiji i njihova primena u savremenoj praksi, [Criminal procedure regulation of special evidentiary actions in the Republic of Serbia and their application in modern practice]. Civitas, 7(2), pp. 36-64

11. Škulić, M. (2007). Krivično procesno pravo, [Criminal Procedural Law]. Beograd, Pravni fakultet Univerziteta u Beogradu i JP Službeni glasnik

12. Škulić, M. (2015). Tajni audio i video nadzor kao posebna dokazna radnja u Zakoniku o krivičnom postupku Srbije, [Secret audio and video surveillance as a special evidentiary action in the Criminal Procedure Code of Serbia]. Tužilačka reč, 28, pp. 24-49

13. Škulić, M. (2016). Posebne dokazne radnje u funkciji suzbijanja terorizma i osnovni pravni aspekti protivterorističkog delovanja vojnih snaga, [Special evidentiary actions in the function of counter-terrorism and basic legal aspects of counter-terrorist activities of military forces]. Vojno delo 6, pp. 275-292 
14. Zakon o osnovama uređenja službi bezbednosti Republike Srbije, [Law on the Bases of Regulation of Republic of Serbia Security Services]. Službeni glasnik RS, no. 116/07 i 72/12

15. Zakon o Vojnobezbednosnoj agenciji i Vojnoobaveštajnoj agenciji, [Law on the Military Security Agency and the Military Intelligence Agency]. Službeni glasnik RS, no. 88/09, 55/12 - decision US and 17/13

16. Zakon o Bezbednosno-informativnoj agenciji, [Law on the Security Information Agency]. Službeni glasnik RS, no. 42/02, 111/09, 65/14 - dicision US, 66/14 and 36/18

17. Zakonik o krivičnom postupku, [Criminal Procedure Code]. Službeni glasnik $R S$, no. 72/11, 101/11, 121/12, 32/2013, 45/13, 55/14 and $35 / 19$

18. Živanović, K. (2018). Posebna dokazna radnja tajnog nadzora komunikacije - Praksa Evropskog suda za ljudska prava u slučaju neobrazložene naredbe suda, [Special evidentiary action of secret surveillance of communication - The practice of the European Court of Human Rights in the case of an unexplained court order]. NBP Žurnal za kriminalistiku i pravo 23(3), pp. 287-310 